\title{
Diphtheria Remains a Threat to Health in the Developing World - An Overview
}

\author{
Ana Luíza Mattos-Guaraldi/+', Lílian Oliveira Moreira*, Paulo Vieira Damasco, \\ Raphael Hirata Júnior
}

Faculdade de Ciências Médicas, Universidade do Estado do Rio de Janeiro, Av. 28 de Setembro 87, fundos, $3^{\circ}$ andar, 20551-030 Rio de Janeiro, RJ, Brasil *Instituto de Biofísica Carlos Chagas Filho, Universidade Federal do Rio de Janeiro,

Rio de Janeiro, RJ, Brasil

Changes in the epidemiology of diphtheria are occurring worldwide. A large proportion of adults in many industrialized and developing countries are now susceptible to diphtheria. Vaccine-induced immunity wanes over time unless periodic booster is given or exposure to toxigenic Corynebacterium diphtheriae occurs. Immunity gap in adults coupled with large numbers of susceptible children creates the potential for new extensive epidemics. Epidemic emergencies may not be long in coming in countries experiencing rapid industrialization or undergoing sociopolitical instability where many of the factors thought to be important in producing epidemic such as mass population movements and difficult hygienic and economic conditions are present. The continuous circulation of toxigenic $\mathrm{C}$. diphtheriae emphasizes the need to be aware of epidemiological features, clinical signs, and symptoms of diphtheria in vaccine era so that cases can be promptly diagnosed and treated, and further public health measures can be taken to contain this serious disease. This overview focused on worldwide data obtained from diphtheria with particular emphasis to main factors leading to recent epidemics, new clinical forms of C. diphtheriae infections, expression of virulence factors, other than toxin production, control strategies, and laboratory diagnosis procedures.

Key words: adherence - Corynebacterium diphtheriae - diphtheria in adults - epidemics - laboratory diagnosis

\section{DIPHTHERIA IN THE VACCINE ERA}

By the beginning of the 1980's, evidences suggested that diphtheria was certainly coming back but not in the same way as before the advent of immunization (Christenson 1986). The widespread availability of diphtheria toxoid led to a marked decrease in the incid-ence of diphtheria and in circulating of toxigenic Corynebacterium diphtheriae organisms resulting in less natural boosting of antibody levels. The level of immunity declines in late childhood and adolescence, depending on the schedule of immunization and the remaining reservoir of $C$. diphtheriae in the population. This fact may lead to gaps in the immunity of the adults and diphtheria outbreaks may occur in subgroups of susceptible individuals despite widespread childhood vaccination. Serological surveys demonstrated that $20 \%$ to $>50 \%$ of adolescents and adults lacked immunity to diphtheria toxin in some areas of the United States of America (US), with particularly low levels among the elderly (Farizo et al. 1993).

In developing countries, high levels of vaccination of infants with diphtheria-tetanus toxoids-pertussis vaccine (DTP) have been achieved following implementation of the Expanded Program on Immunization of the World Health Organization (WHO) in the 1970's (WHO 1984).

Financial support: CNPq, Capes, Pronex, Faperj, SR-2/Uerj ${ }^{+}$Corresponding author. Fax: +55-21-2587.6476. E-mail: guaraldi@uerj.br

Received 31 July 2003

Accepted 10 November 2003
Despite the widespread use of immunization, diphtheria remains endemic in several regions (Galazka \& Robertson 1995) including Africa, India (Singh et al. 1999), Bangladesh, Vietnam (Kneen et al. 1998), the tropics and areas of South America (Cárdenas et al. 1972, MacQueen 1997), including Brazil (Formiga 1985). Several countries where coverage has been high for 5-10 years have reported diphtheria outbreaks. High case fatality rates, a large proportion of patients with complications, and their occurrence in both young and older age groups characterized these outbreaks (Galazka \& Robertson 1995).

The reasons for reemergence of epidemic in countries where immunization programs had nearly eliminated diphtheria are not fully understood but are thought to include the introduction of toxigenic $C$. diphtheriae strains of a new biotype into the general population besides the low coverage with diphtheria vaccine among children and the large gap of immunity among adults. Historical data showed that a shift of the disease to older ages began before mass immunization was introduced. Crowding and poor personal hygiene have contributed to transmission and increase in diphtheria infections in adults.

Importation of the microorganism from regions where diphtheria remains endemic also poses a constant threat, particularly among subgroups of individuals with low vaccination levels (Farizo et al. 1993). Between 1986 and 1994 the majority of toxigenic strains isolated in the United Kingdom was imported from the Indian subcontinent, Pakistan, Africa, Somalia, and the Tropics (Mac Queen 1997). In the Netherlands, the introduction of diphtheria into religious communities, refusing vaccination constituted a danger of spread of the bacterium, as more than $60 \%$ of orthodox reformed persons had no protective diphtheria antibody levels (Melker et al. 1999). 
The role of coetaneous diphtheria has been emphasized by several diphtheria outbreaks among US homeless alcoholic and impoverished groups (Galazka 2000, Markina et al. 2000). Coetaneous diphtheria has been reported with variable rates of isolation depending on the geographical location. Reports from Seattle (US) and Rangoon (Burma) documented 50-60\% of coetaneous diphtheria in contrast with $10-20 \%$ observed in Louisiana, Alabama (US) and Rio de Janeiro (Brazil). Rates of isolation were high, 40-50\%, in other places like Ceylon, Uganda, and Bengal (India), as well as Zaire and Amazonas (Brazil), $30-40 \%$. Geographic variations in rates occur owing to nation-to-nation differences in reporting. The right selection of methods to detect diphtheria bacilli may contribute to declining of isolation rates, since a "diphtheroid" may be considered a non-toxigenic $C$. diphtheriae without an adequate specification (Formiga \& Mattos-Guaraldi 1993, Macambira et al. 1994, Galazka \& Robertson 1995).

Since 1990, diphtheria reemerged in the Russian Federation and spread to all Newly Independent States (NIS) and Baltic states. Proportion of diphtheria cases in people $\geq 15$ years old ranged from $64 \%$ to $82 \%$. By the beginning of 1999 , the diphtheria epidemic had caused $\geq 157,000$ cases and 5000 deaths. Adults 40-49 years old had extremely high incidence accounted for nearly half of all deaths in some countries. Older adults (> 50 years of age) had relatively few cases. The epidemic demonstrated conclusively the potential susceptibility of adults to diphtheria in the vaccine era (Galazka 2000). Awareness of characteristics of the largest diphtheria epidemic in the last 30 years that seized several European countries may be used to help predict the spread of future epidemics. Important characteristics included, among several other factors, the high proportion of infected adults, emergence of distinct epidemic clonal group, a progressive spread of disease from urban centers to rural areas and, transition from initial amplification of disease in groups with high rates of close contacts in focalized well-distinguished outbreaks to a more generalized epidemic. The spread of NIS epidemic was facilitated by large scale population movements; socioeconomic instability, partial deterioration of health infrastructure; delay in implementing measures to control epidemic; inadequate information for physicians and the public; lack of adequate supplies for prevention and treatment in most of the countries (De Zoysa et al. 1995, Popovic et al. 1995, Dittmann et al. 2000).

Evidence suggested that a large proportion of the disease among adults was transmitted from ill or asymptomatic children and that schoolchildren played an important role in amplifying the overall epidemic. Outbreaks with adult-to-adult transmission occurred in institutional setting including military units, neuropsychiatry hospitals, and concentrations of homeless people. However, clusters of cases were rare in routine work settings, and the carrier rates among adult contacts of cases were usually low (Dittmann et al. 2000, Galazka 2000).

Although adolescents and adults made up a majority of reported cases during the NIS epidemic, diphtheria continues to kill many children in industrialized and developing countries (Singh et al. 1999).

\section{DIPHTHERIA IS STILL WITH US}

Brazil is a developing country presenting a very large territory $\left(8,547,403.5 \mathrm{~km}^{2}\right)$ with varied geographic, social and economic conditions unfavorable for prevention not only of diphtheria, but also other communicable diseases. Since 1980, even before public health authorities have initiated efforts to vaccinate children, the number of reported diphtheria cases decreased. However, accurate data have not been available, particularly from the North and Central-West states, because reporting is infrequent, laboratory confirmation is not available, and the extent of carriers is not clearly known. Between 1980-1989 diphtheria outbreaks were reported in diverse geographic areas in Brazil such as Piauí, Ceará, Rio Grande do Norte, Pernambuco, Amazonas, and Santa Catarina. Morbidity was associated with poor vaccination status and pre-schoolage. Clinical disease occurred in both non-vaccinated susceptible persons and persons who had a history of some previous vaccination. During an outbreak in a northern state only $25 \%$ of the children presented history of previous vaccination (Mattos-Guaraldi \& Formiga 1991a). During 1980-1999, a total of 27,134 diphtheria cases were reported to local public health authorities. Almost half of the cases were reported in the Northeast region. Only 9\% (2409) of these cases were reported during 1990 's. A high number of cases $(715 ; 26 \%)$ were also reported in the Southeast region (Funasa 2002). Although diphtheria is thought to be declining in Brazil, the disease remain endemic in most states through the last two decades with a case-fatality range of $5 \%$ to $10 \%$.

C. diphtheriae skin carriers (13.9\% with nontoxigenic and $1.19 \%$ with toxigenic bacilli) were found among schoolchildren in the city of Rio de Janeiro. Diphtheria bacilli was found infecting $15.09 \%$ of various types of coetaneous lesions including ecthyma, ulcers, secondary infected abrasions, impetigo, infected burn wounds, and even ingrown nail (Nogueira et al. 1986).

Over the past 10 years, $C$. diphtheriae is found infecting unusual anatomic sites such as ears, conjunctiva, and vagina. Drug abusers who are homosexual, bisexual, or who develop AIDS are at great risk of acquiring infections (Halioua et al. 1992, Formiga \& Mattos-Guaraldi 1993, Hogg et al. 1996, Kneen et al. 1998). In Brazil, C. diphtheriae was isolated from sperm and from coetaneous ulcers due to Leishmania brasiliensis brasiliensis (Machado et al. 1989, Formiga \& Mattos-Guaraldi 1993, Vera et al. 2002). Recently, two cases illustrated the persistence of $C$. diphtheriae in the general population and sustained potential to produce disease among individuals with neoplastic disease (Mattos-Guaraldi et al. 2001c). In the year 1999, occurred a case of diphtheria in a 32-year-old woman, who developed a sore throat immediately after participating on a five-day meeting in Rio de Janeiro with European workers. She gave history of complete pediatric immunization (DTP) and three doses of adult formulation tetanus and diphtheria toxoid (dT) two years earlier. Clinical diagnosis of diphtheria was not made until microbiologic examination of specimens 
confirmed toxigenicity of $C$. diphtheriae var. gravis, a biotype currently found circulating within Europe, where diphtheria remains epidemic. This case reinforces the potential susceptibility of Brazilian adults to epidemic diphtheria in the vaccine era (Mattos-Guaraldi et al. 2001b).

$C$. diphtheriae systemic infections have been also subject of concern in France (Patey et al. 1997). Cases of endocarditis due to non-toxigenic strains were also reported in Switzerland (Funke et al. 1999), Australia (Hogg et al. 1996), and Argentina (Leardini et al. 2002). A fatal case of endocarditis due to a toxigenic $C$. diphtheriae strain of the atypical sucrose fermenting biotype was reported in Rio de Janeiro, Brazil (Mattos-Guaraldi \& Formiga 1998).

As in industrialized countries, lack of immunity in adults is a reason for concern (Filardy et al. 2000, Formiga \& Mattos-Guaraldi 2001). Increasing international travel, emergence of invasive and epidemic clones and unfavorable social conditions may also influence in the spread of diphtheria in Brazil and require achieving and maintaining high coverage with diphtheria toxoidcontaining vaccines in both children and adults.

\section{CLINICAL FEATURES}

C. diphtheriae infection should be suspected in any patient who lives near an endemic area where clinically significant outbreaks could occur in the future. However, at present, most physicians have little experience in diagnosing and treating diphtheria. The success in preventing the disease also has made many laboratories lax identification of $C$. diphtheriae. The tendency to disregard pathogens such as $C$. diphtheriae can lead to delayed or inappropriate therapy. Maintenance of a high level of clinical awareness of diphtheria, prompt investigation of sporadic cases with systematic identification and management of close contacts is needed to prevent dissemination of diphtheria bacilli.

Because respiratory diphtheria may progress rapidly, a high index of suspicion needs to be maintained. The clinical features among unvaccinated patients still similar to those that were observed in the pre-vaccine era. Despite the shift to an older median age among patients, diphtheria remains a potentially fatal disease presenting with clinically membranous pharyngitis, often with complications of myocarditis and less commonly neuritis and respiratory coinfections-pneumonia or bronchitis. Clinical attention should be directed to signs of airway obstruction, acute systemic toxicity, and toxin mediated myocarditis and neuritis. Myocarditis may present acutely, with congestive heart failure and circulatory collapse, or more insidiously, with progressive dyspnea, weakness, diminished heart sounds, and gallop rhythm. Electrocardiograph abnormalities such T-wave alterations and first-degree heart block, may occur in the absence of clinical signs and progress to severe block, atrioventricular dissociation, and other potentially fatal arrhythmia. Mechanical airway obstruction and myocarditis account for most deaths related to diphtheria. Cardiovascular toxicity may be evident leading to paralysis of respiration (Farizo et al. 1993, Macambira et al. 1994, Usmanov et al. 2000).
During diphtheria outbreak in St. Petersburg, catarrhal disease without membranes was present in $67.5 \%$ patients; $1.8 \%$ patients had membranes on larynx or in the lower respiratory tract; $2.3 \%$ died. For $98 \%$ of the patients the diagnosis was confirmed by a positive throat culture growing toxigenic strains (Rakhmanova et al. 1996). Patients may also present with one of the toxin-induced complications of the illness without any prominent evidence of local nasopharyngeal infection (Usmanov et al. 2000).

General poor health and depressed respiratory defense mechanisms also predispose individuals to the agent of diphtheria (Halioua et al. 1992, Formiga \& Mattos-Guaraldi 1993, Wilson 1995, Hogg et al. 1996). Investigation on immunity to diphtheria in advanced cancer patients demonstrated that about $30 \%$ had no antidiphtheria immunity. Half of the patients $(35 \%)$ with antidiphtheria immunity presented lower antibody level (Buzzi \& Sala 1980). C. diphtheriae strains were isolated from bronchoalveolar washing and cancer skin lesion specimens of hospitalized adults with blastoma. The first patient presented congestive cardiopathy and developed a rapidly fatal progressive illness. The second one recovered well from resection of the tissue compromised by the tumor regaining his baseline state of health (MattosGuaraldi et al. 2001c). Children with malignancies who are receiving chemotherapy should not be denied immunization with active vaccines (Orgel et al. 1977). Laboratories should be alert to the possibility of the isolation of $C$. diphtheriae especially from uncommon anatomic sites of immunocompromised hosts.

\section{EPIDEMIC AND ENDEMIC $C$. DIPHTHERIAE STRAINS}

Characterization of bacteriological aspects of endemic and epidemic strains and determination of genetic relatedness of $C$. diphtheriae isolates from geographically diverse areas provide valuable information for epidemiological studies attempting to determine sources and vehicles of transmission of the organism through local communities and countries.

The massive importation of epidemic strains into a susceptible population combined with social factors certainly facilitated the spread of the epidemic throughout European countries. However, the source of the epidemic strains remains unclear (Popovic et al. 1996). Molecular characterization by ribotyping and/or random amplification polymorphic DNA (RAPD-PCR) of the Russian $C$. diphtheriae isolates indicated that a distinct clonal group emerged in Russia in 1990 about the time epidemic began. The emergence of the epidemic clone of toxigenic $C$. diphtheriae var. gravis was first documented in 1987 and accounted for an increasing proportion of the strains isolated from cases in sentinel areas as the epidemic progressed (Dittmann et al. 2000).

Emergence of related nontoxigenic $C$. diphtheriae var. mitis strains also occurred in Switzerland, Germany, and France. In Switzerland, isolates came from skin infections of drug users, homeless persons, prisoners and elderly orthopedic patients. Tetracycline resistance was typical for the isolates from Swiss injecting drug users (Funke et al. 1999). 
Since 1970's, C. diphtheriae var. mitis of the sucrosefermenting biotype has been related with diphtheria outbreaks in different regions of Brazil and other South American countries (Cárdenas et al. 1972, Formiga et al. 1981). The wide dissemination of the sucrose-fermenting biotype, uncommonly found in most industrialized countries became a subject of concern. Biological and molecular characterization of Brazilian $C$. diphtheriae isolates indicated genetic diversity within the species (Pereira 2001). The introduction of this unusual biotype, which then spread from person to person had some selective advantage, such as increased virulence or enhanced ability to colonize and spread (Mattos-Guaraldi \& Formiga 1991a, Mattos-Guaraldi et al. 2000a). However, the prevalence of the sucrose fermenting biotype in our community remains not understood.

Little is known about initialization, buildup and spread of diphtheria epidemic. There are many unanswered questions with respect to the shift in the biotypes of $C$. diphtheriae strains, increase in the case fatality ratio and change of the age distribution of diphtheria cases toward older children and adults (Popovic et al. 1995, Galazka 2000). Additional studies about vaccine components that may contribute to protection and mechanisms of virulence of diphtheria bacilli other than toxin production are needed.

\section{VIRULENCE FACTORS, OTHER THAN TOXIN}

The worst epidemic of diphtheria in post vaccination era has drawn attention to the incomplete understanding of the epidemiology of diphtheria and virulence factors of C. diphtheriae. Host factors (such as antimicrobial immunity) could contribute to the epidemic potential of a newly introduced strain, but microbial factors may not be excluded (Vitek \& Wharton 1998, Dittmann et al. 2000, Mattos-Guaraldi et al. 2000b, Vitek et al. 2000). However, microbial factors that distinguish epidemic from endemic strains have not been identified. The fact that specific epidemic clones are responsible for severe outbreaks of diphtheria with thousands of deaths in industrialized countries make the argument that $C$. diphtheriae virulence factors, other than toxin, are important for the potential to cause human disease. The occurrence of diphtheria among immunized persons, the increasing frequency of cases of endocarditis caused by non-toxigenic invasive clones associated to the prevalence of an atypical biotype of $C$. diphtheriae var. mitis responsible for a high mortality rate of respiratory diphtheria in Brazil also points the importance of the other microbial factors as well (MattosGuaraldi \& Formiga 1998, Mattos-Guaraldi et al. 2000a, 2001b, Formiga \& Mattos-Guaraldi 2001).

C. diphtheriae is able to overcome host conditions, in part by producing siderophores or other iron-uptake mechanisms that allow them to express virulence factors such as toxins and enzymes. Recent results also imply regulation of adherence and slime production as part of a global response to iron-limited environmental conditions that includes derepression of genes for the synthesis of cytotoxin and siderophores and for transport of the $\mathrm{Fe}$ (III)-siderophore complexes (Moreira et al. 2003).
Differences on adhesiveness among diphtheria strains may be related to the prevalence of one biotype over the other (Mattos-Guaraldi \& Formiga 1991a,b). The adhesive activity is important for colonization and pathogenicity of bacterial species. Some of the main primary approaches and new developments in the study of the molecular basis of the adhesive process of $C$. diphtheriae are reviewed along with a discussion of the potential importance of haemagglutinins, exposed sugar residues, hydrophobins and trans-sialidase enzymes as adhesins of strains of the sucrose fermenting and non-fermenting biotypes (MattosGuaraldi et al. 2000a).

Recently, bacterial surface proteins of 67 and $72 \mathrm{kDa}$, named 67-72 p, were isolated and related to attachment of C. diphtheriae to human erythrocytes. Non-fimbrial 6772 p may play a key role in bacterial attachment to different host cells, facilitating the early step in $C$. diphtheriae pathogenesis (Colombo et al. 2001). Although diphtheria bacilli are generally considered an extracellular coloniser (Funasa 2002), recent investigations showed the ability of $C$. diphtheriae to survive within cultured epithelial cells. Thus, entry into epithelial cells may provide a protected niche for toxigenic diphtheria bacilli survival, which may help to explain the ability of $C$. diphtheriae to persist in the respiratory tract despite antimicrobial therapy and antitoxin response. Additionally, invasion may be also relevant in vivo, allowing $C$. diphtheriae to breach the epithelial cell barrier and enter deeper tissues (Hirata $\mathrm{Jr}$ et al. 2002).

\section{NIS CONTROL EPIDEMIC MEASURES}

Initial control epidemic measures adopted improving routine childhood coverage rates and immunizing adults in "high-risk" occupational groups was unsuccessful. The traditional approach used to control diphtheria, and the delays in implementing more intensive measures were followed by rapid spread of the epidemic (Vitek et al. 2000). The continued spread of diphtheria led to a directive to vaccinate the $>120$ million Russian adults. Efforts focused on immunizing adults at work sites, followed by nonworking adults. The plan for coordinated action to control epidemic diphtheria in the countries of the former USSR, elaborated in 1995 by WHO in close collaboration with other governments and international agencies, was based on initiate mass immunization as rapidly as possible of all age group in the population; provide early detection and proper management of diphtheria cases; provide early identification and proper management of close contacts of diphtheria cases (Dittmann et al. 2000).

\section{LABORATORY DIAGNOSIS}

In many advanced cases of the disease, the clinical diagnosis would normally precede microbiologic diagnosis. However, it is sometimes often difficult to diagnose diphtheria clinically, particularly in those countries where the disease is rarely seen. Accurate microbiologic diagnosis is crucial and is always regarded as being complementary to clinical diagnosis. Laboratories must be alert to possible serious epidemiological situations. In Brazil, the current reporting of localized outbreaks attracted justifiable attention and the lack of 
expertise and materials to reliably identify toxigenic $C$. diphtheriae of most Public Health Laboratories stimulated the search for laboratory tests for differential diagnosis of diphtheria based on the porphyrin production (fluorescence) and the double sugar-urease (DSU) tests (test for glucose and maltose utilization and urease activity) and radial immunodiffusion (RID) toxigenicity assay (Formiga 1985). Recently, as a result of the recent upsurge in disease activity, the WHO recently published a manual with current recommendations for isolation and identification of toxigenic $C$. diphtheriae at various laboratory levels (Efstratiou et al. 2000).

The rarity of cases and the expense and complexity associated with laboratory diagnosis provided many countries with the indication to cease screening throat specimens for $C$. diphtheriae. Since diphtheria remain endemic in Brazil, expertise and recognition of the organism should not decline. Laboratory errors may be significant in view of the several clinical forms which disease can take in addition to the frequency of cases due to non-toxigenic C. diphtheriae, including sucrose-fermenting strains (Formiga \& Mattos-Guaraldi 1993, 2001, Pennie et al. 1996, Mattos-Guaraldi \& Formiga 1998). The fermentation of sucrose generally used to exclude diphtheria bacilli may lead to errors, particularly in regions of the world where isolation of atypical C.diphtheriae strains is very common (Formiga et al. 1981, Mattos-Guaraldi \& Formiga 1991a, 1998).

Given the immense public health significance attached to the isolation of $C$. diphtheriae, the delay between isolation of a suspicious organism and the results of toxigenicity tests can provoke anxiety among laboratory staff, clinicians, and public health officials. Phenotypic confirmation of toxigenicity for microbiological diagnosis of diphtheria is recommended (Formiga, 1985, 1986, Formiga \& Mattos-Guaraldi 1993, 2001, Claridge \& Springel 1995, Efstratiou et al. 2000). Classical tests commonly used to demonstrate the toxigenicity of a $C$. diphtheriae strain (Elek and IDR test) give a delayed answer to the diagnosis (usually more than $48 \mathrm{~h}$ ) and are time-consuming to set up. A rapid immunochromatographic (ICS) method for detection of diphtheria toxin has recently been developed (Engler et al. 2002). During epidemics, field studies within the former USSR showed $99 \%$ correlation between the Elek and ICS test (Koslov et al. 2000). In contrast, the results of Brazilian endemic and epidemic $C$. diphtheriae strains tested by the ICS and Elek tests showed $76 \%$ correlation (Mattos-Guaraldi et al. 2001a). The use of polymerase chain reaction (PCR) for rapid screening of toxigenic $C$. diphtheriae has also been described. However, data are not yet sufficient for PCR to be accepted as a criterion for laboratory confirmation. PCR may be used with caution because some isolates of $C$. diphtheriae present toxin genes but fail to express a biologically active toxin (Pallen et al. 1994, Efstratiou et al. 1998, 2000).

Immunization protects against toxigenicity but not against invasiveness of the organism. Thus, toxigenicity testing is only an indicator of the current status of the microbe and may provide a false sense of security.

\section{CONCLUDING REMARKS}

Despite overall progress, devastating epidemics in human history occurred in XX century. These episodes illustrate the unpredictability of infectious disease emergence and death rates (CDC 1999). The reemergence of diphtheria in European countries warns for a potential for epidemics of vaccine-preventable diseases elsewhere. Circulation of toxigenic strains continues to present a threat to industrialized and developing countries and require achieving and maintaining high coverage with diphtheria toxoid-containing vaccines in both children and adults. The worst diphtheria epidemic of the last decades forced a new generation of clinicians, laboratories, and epidemiologists worldwide to relearn old lessons and develop new methods in the prevention, control, and treatment of diphtheria. In countries were diphtheria incidence is still relatively high and coverage is still inadequate laboratory support should be supplied due to ongoing severe limitations on basic laboratory capacity. Continued investment in improved vaccines, control strategies, training and laboratory techniques remain necessary.

\section{REFERENCES}

Buzzi S, Sala G 1980. Immunity to diphtheria in advanced cancer patients. Ateneo Parmense Acta Biomed 51: 113116.

Cárdenas R, Prieto G, Vargas J, Martinez A 1972. Corynebacterium diphtheriae. Características de cepas aisladas recientemente en Maracaibo - Venezuela. Kasmera 4: 185198.

CDC-Centers for Disease Control and Prevention 1999. Control of infectious disease. Historical article. Mor Mortal Wkly Rep 48: 621-629.

Christenson B 1986. Is diphtheria coming back? An Clin Res 18: 69-70.

Claridge JE, Sprigel CA 1995. Corynebacterium and miscellaneous irregular gram-positive rods, Erysipelothris and Gardnerella. In PR Murray, EJ Baron, MA Pfaller, FC Tenover, RH Yolken (eds), Manual of Clinical Microbiology, 6th ed., American Society for Microbiology, Washington DC, p. 357-373.

Colombo AV, Hirata Jr R, Souza CMR, Monteiro-Leal LH, Previato JO, Formiga LCD, Andrade AFB, Mattos-Guaraldi AL 2001. Corynebacterium diphtheriae surface proteins as adhesins to human erythrocytes. FEMS Microbiol Lett 197: 235-239.

De Zoysa A, Efstratiou A, George RC, Jahkola M, VuopioVarkila J, Deshevoi S, Tseneva G, Rikushin Y 1995. Molecular epidemiology of Corynebacterium diphtheriae from Northwestern Russia and surrounding countries studied by using ribotyping and pulsed-field gel electrophoresis. J Clin Microbiol 33: 1080-1083.

Dittmann S, Wharton M, Vitek C, Ciotti M, Galazka A, Guichard S, Hardy I, Kartoglu U, Koyama S, Kreysler J, Martin B, Mercer D, Rønne T, Roure C, Steinglass R, Strebel P, Sutter R, Trostle M 2000. Successful control of epidemic diphtheria in the states of the former Union of Soviet Socialist Republics: lessons learned. J Infect Dis 181: 10-22.

Efstratiou A, Engler KH, Dawes CS, Sadic D 1998. Comparison of phenotypic and genotypic methods for detection of diphtheria toxin among isolates of pathogenic corynebacteria. J Clin Microbiol 36: 3173-3177.

Efstratiou A, Engler KH, Mazurova IK, Glushkevish T, Vuopio- 
Varkila J, Popovic T 2000. Current approaches to the laboratory diagnosis of diphtheria. J Infect Dis 181: 138-145.

Engler K, Efstratiou A, Norn D, Kozlov RS, Selga I, Glushkevich TG, Tam M, Melnikov VG, Mazurova IK, Kim VE, Tseneva GY, Titov LP, George RC 2002. Immunochromatographic strip test for rapid detection of diphtheria toxin: description and multicenter evaluation in areas of low and high prevalence of diphtheria. J Clin Microbiol 40: 80-83.

Farizo KM, Strebel PM, Chen RT, Kimbler A, Cleary TJ, Cochi SL 1993. Fatal respiratory disease due to Corynebacterium diphtheriae: case report and review of guidelines for management, investigation and control. Clin Infect Dis 16: 59-68.

Filardy AD, Hirata Jr R, Villela LHC, Napoleão F, Formiga LCD, Andrade AFB, Mattos-Guaraldi AL 2000. Potential susceptibility to diphtheria among adolescents and adults in Rio de Janeiro. XXI Congresso Brasileiro de Microbiologia, Foz do Iguaçu, PR.

Formiga LCD 1985. New possibilities for the laboratory diagnosis of diphtheria. Brazi J Med Biol Res 18: 401-402.

Formiga LCD 1986. Diagnóstico microbiológico da difteria. Rev Bras Patol Clin 22: 52-58.

Formiga LCD, Mattos-Guaraldi AL 1993. Diphtheria: current status and laboratory procedures for diagnosis. Rev Bras Patol Clin 29: 93-96.

Formiga LCD, Mattos-Guaraldi AL 2001. Difteria - Profissionais susceptíveis, diagnóstico, vacinação e reparação de danos. J Bras Patol 37: 288-289.

Formiga LCD, Mattos-Guaraldi AL, Rodrigues HA, Pessôa MHR, Lourenço NJ 1981. Isolamento de bacilo diftérico toxinogênico fermentador de sacarose no município do Rio de Janeiro. XI Congresso Brasileiro Microbiologia, Florianópolis, Santa Catarina.

Funasa-Fundação Nacional da Saúde 2002. Difteria: situação atual da doença. Available from URL: http://www.funasa. gov.br/guia_epi/htm/doenças/difteria/index.htm Mar 23.

Funke G, Altwegg M, Frommelt L, Von Graevenitz A 1999. Emergence of related nontoxigenic Corynebacterium diphtheriae biotype mitis strains in Western Europe. Emerg Infect Dis 5: 477-480.

Galazka AM 2000. The changing epidemiology of diphtheria in the vaccine era. $J$ Infect Dis 181: 2-9.

Galazka AM, Robertson SE 1995. Diphtheria: changing patterns in the developing world and the industrialized world. Eur J Epidemiol 11: 107-117.

Halioua B, Patey O, Casciani D, Emond JP, Dublanchet A, Malkin JE, Lafaix C 1992. Cutaneous diphtheria in a patient with HIV infection. Ann Dermatol Venereol 18: 874-877.

Hirata Jr R, Napoleão F, Monteiro-Leal LH, Andrade AFB, Nagao PE, Formiga LCD, Fonseca LS, Mattos-Guaraldi AL 2002. Intracellular viability of toxigenic Corynebacterium diphtheriae strains in Hep-2 cells. FEMS Microbiol Lett 215: 115-119.

Hogg GG, Strachan JE, Huayi L, Beaton SA, Robinson PM, Taylor K 1996. Non-toxigenic Corynebacterium diphtheriae var. gravis: evidence for an invasive clone in a SouthWestern Australian community. Med J Aust 164: 72-75.

Kneen R, Phan NG, Solomon T, Tran TM, Nguyen TT, Tran BL, Wain J, Day NP, Tran TH, Parry CM, White NJ 1998. Penicillin vs erythromycin in the treatment of diphtheria. Clin Infect Dis 27: 845-850.

Koslov R, Ketchikova O, Sukhoukova M 2000. Field study of the new immunochromatographic method for toxin detection in Corynebacterium diphtheriae in Smolensk (Russia). Sixth International Meeting of the European Laboratory Working Group on Diphtheria, European
Commission, Brussels, Belgium, Abstracts Book, A 4.5, p. 53.

Leardini NA, Prieto MA, Martinez CP, Aguerre LA 2002. Current clinical and epidemiological aspects of Corynebacterium diphtheriae infections in Argentina. Seventh International Meeting of the European Laboratory Working Group on Diphtheria, European Commission, Vienna, Austria, Abstracts Book, A 2.9, p. 49.

Macambira RP, Formiga LB, Formiga LCD 1994. Difteria: o grave prognóstico brasileiro. J Bras Med 66: 69-81.

Machado TL, Formiga LCD, Machado RD, Silva R 1989. Isolamento de Corynebacterium diphtheriae de líquido espermático. Mem Inst Oswaldo Cruz 84: 241-243.

MacQueen S 1997. Diphtheria: a changing pattern. Nursing Times 93: 57-62.

Markina SS, Marsimova NM, Vitek CR, Bogatyreva EY, Monisov AA 2000. Diphtheria in the Russian Federation in the 1990s. J Infect Dis 181: 27-35.

Mattos-Guaraldi AL, Formiga LCD 1998. Bacteriological properties of a sucrose fermenting Corynebacterium diphtheriae strain isolated from a case of endocarditis. Curr Microbiol 37: 156-158.

Mattos-Guaraldi AL, Formiga LCD 1991a. Corynebacterium diphtheriae e difteróides: ensaios de aderência. Rev Bras Pat Clin 27: 53-60.

Mattos-Guaraldi AL, Formiga LCD 1991b. Relationship of biotype and source to the hemagglutination and adhesive properties of Corynebacterium diphtheriae. Braz J Med Biol Res 24: 399-406.

Mattos-Guaraldi AL, Engler KH, Tam M, Fairbairn-Coelho FEMR, Moreira LO, Pimenta FP, Pereira GA, Hirata Jr R, Formiga LCD 2001a. The immunochromatographic method for toxin detection and the King-DSU screening procedures as alternative in rapid laboratory diagnosis of Corynebacterium diphtheriae. 101st General Meeting American Society for Microbiology, Orlando, Florida.

Mattos-Guaraldi AL, Formiga LCD, Camello TCF, Pereira GA 2000a. A diphtheria screening method. Sixth International Meeting of the European Laboratory Working Group on Diphtheria, European Commission, Brussels, Belgium, Abstracts Book, A 4.3, p. 51.

Mattos-Guaraldi AL, Formiga LCD, Camello TCF, Pereira GA, Hirata Jr R, Faria LMD, Halpern M 2001c. Corynebacterium diphtheriae threats in cancer patients. Rev Argentina Microbiol 33: 96-100.

Mattos-Guaraldi AL, Formiga LCD, Marques EA, Pereira GA, Moreira LO, Pimenta FP, Camello TCF, Oliveira EF 2001b. Diphtheria in vaccinated adult in Rio de Janeiro, Brazil. Braz J Microbiol 32: 236-239.

Mattos-Guaraldi AL, Formiga LCD, Pereira GA 2000b. Cell surface components and adhesion in Corynebacterium diphtheriae. Microbes Infect 2: 1507-1512.

Melker HE, Berbers GAM, Nagelkerke NJD, Conyn V, Sapendonck MAE 1999. Diphtheria antitoxin levels in the Netherlands: a population-based study. Emerg Infect Dis 5: 694-700.

Moreira LO, Andrade AFB, Vale MD, Souza SM, Hirata Jr R, Asad LMOB, Asad NR, Monteiro-Leal LH, Previato JO, Mattos-Guaraldi AL 2003. Iron limitation effects on adherence and cell surface carbohydrates of Corynebacterium diphtheriae. Appl Environ Microbiol 69: 5907-5913.

Nogueira SA, Formiga LCD, Assis ACB, Rangel LB, Camello TCF 1986. Estudo de portadores cutâneos do Corynebacterium diphtheriae em escolares do município do Rio de Janeiro. Rev Soc Bras Med Trop 19: 34-35. 
Orgel HA, Hamburger RN, Mendelsin LM, Miller JR, Kung FH 1977. Antibody response in normal infants receiving chemotherapy for congenital neuroblastoma. Cancer 40: 994-997.

Pallen MJ, Hay A, Puckey LH, Efstratiou A 1994. Polymerase chain reaction for screening clinical isolates of corynebacteria for the production of diphtheria toxin. J Clin Pathol 47: 353-356.

Patey O, Bimet F, Riegel P, Halioua B. Emond JP, Estrangin E, Dellion S, Alonso JM, Kiredjian M, Dublanchet A, Lafaix C 1997. Clinical and molecular study of Corynebacterium diphtheriae systemic infections in France. J Clin Microbiol 35: 441-445.

Pennie RA, Malik AS, Wilcox L 1996. Misidentification of toxigenic Corynebacterium diphtheriae as a Corynebacterium species with low virulence in a child with endocarditis. J Clin Microbiol 34: 1275-1276.

Pereira GA 2001. Aspectos Fenotípicos e Genotípicos de Amostras de Corynebacterium diphtheriae Isoladas no Brasil, MSc Thesis, Faculdade de Ciências Médicas, Universidade do Estado do Rio de Janeiro, Rio de Janeiro.

Popovic T, Kombarova SY, Reeves MW, Nakao H, Mazurova IK, Wharton M, Wachsmuth IK, Wenger JD 1996. Molecular epidemiology of diphtheria in Russia, 1985-1994. J Infect Dis. 174: 1064-1072.

Popovic T, Wharton M, Wenger, JD, Mc Entyre L, Wachsmuth IK 1995. Are we ready for diphtheria? J Infect Dis 171:
765-767.

Rakhmanova AG, Lumio J, Groundström K, Valova E, Nosikova E, Tanasijchuk T, Saikku J 1996. Diphtheria outbreak in St. Petersburg: clinical characteristics of 1860 adult patients. Scand J Infect Dis 28: 37-40.

Singh J, Harit AK, Jain DC, Panda RC, Tewari KN, Bhatia R 1999. Diphtheria is declining but continues to kill many children: analysis of data from a sentinel center in Delhi. Epidemiol Infect 123: 209-215.

Usmanov I, Favorov MO, Chorba TL 2000. Universal immunization: the diphtheria control strategy of choice in the Republic of Tajikistan, 1993-1997. J Infect Dis 181: 86-93.

Vera LA, Macedo VO, Magalhães AV, Ciuffo IA, Santos CG, Santos JB 2002. Cutaneous leishmaniotic ulcers with Corynebacterium diphtheriae. Rev Soc Bras Med Trop 35: 311-313.

Vitek CR, Wharton M 1998. Diphtheria in the former Soviet Union: reemergence of pandemic disease. Emerg Infect Dis 4: 539-550.

Vitek CR, Bogatyreva EY, Wharton M 2000. Diphtheria surveillance and control in the Former Soviet Union and the Newly Independent States. J Infect Dis 181: 23-26.

WHO-World Health Organization 1984. Expanded program on immunization. Feasibility of elimination of vaccinepreventable disease. Wkly Epidemiol Rec 59: 143-145.

Wilson AP 1995. The return of Corynebacterium diphtheriae: the rise of nontoxigenic strains. J Hosp Infect 30: 306-312. 